p-ISSN : 2597-8977

e-ISSN : 2597-8985

Roslina*)

Jurusan Biologi Pascasarjana Universitas Negeri Makassar

Nurhayati B

Jurusan Biologi FMIPA

Universitas Negeri Makassar

Rachmawaty

Jurusan Biologi FMIPA

Universitas Negeri Makassar
*) Correspondence Author: roslina95@yahoo.com

\section{EFEKTIVITAS PEMANFAATAN MODUL JARINGAN PADA \\ TUMBUHAN BERBASIS PENDEKATAN SAINTIFIK DAN \\ BUKU PAKET BIOLOGI TERHADAP MOTIVASI BELAJAR \\ PESERTA DIDIK}

Abstrak: Efektivitas pemanfaatan modul jaringan pada tumbuhan berbasis pendekatan saintifik dan buku paket biologi dapat mendorong pemahaman peserta didik terhadap materi pembelajaran dan memberikan keseimbangan, melatih serta memperkuat kompetensi peserta didik dalam hal sikap, pengetahuan dan kemampuan secara utuh dalam meningkatkan motivasi belajar peserta didik. Kegiatan pembelajaran dapat berhasil dengan baik, apabila ada peran guru dalam proses pengajaran. Keberhasilan ini banyak bergantung pada usaha guru dalam membangkitkan motivasi belajar peserta didik. Oleh karena itu, penting menciptakan kondisi tertentu agar peserta didik selalu termotivasi dan ingin terus belajar. Penelitian ini termasuk penelitian Quasi Experimental. Populasi dalam penelitian ini adalah seluruh rombongan belajar peserta didik di SMA Negeri 9 Pinrang tahun ajaran 2020/2021 yang terdiri dari tiga rombongan belajar. Penentuan sampel penelitian dilakukan dengan teknik simple random sampling. Teknik pengumpulan data menggunakan angket motivasi belajar. Teknik analisis data dilakukan secara deskriptif dan analisis secara inferensial dengan bantuan program aplikasi IBM SPSS Statistic versi 22 for Windows. Hasil penelitian menunjukkan bahwa (i) motivasi belajar peserta didik melalui pemanfaatan modul jaringan pada tumbuhan berbasis pendekatan saintifik berada pada kategori tinggi, (ii) motivasi belajar peserta didik melalui pemanfaatan buku paket biologi berada pada kategori rendah, dan (iii) ada perbedaan motivasi belajar peserta didik melalui pemanfaatan modul jaringan pada tumbuhan berbasis pendekatan saintifik dan buku paket biologi.

Kata Kunci: Modul Jaringan pada Tumbuhan Berbasis Pendekatan Saintifik, Buku Paket Biologi dan Motivasi Belajar.

Abstract: The effectiveness in utilizing the module of network in plants based on scientific approach and biology package books can encourage students understanding of learning materials and provide balance, train and strengthen the competence of students in terms of attitude, knowledge and abilities as a whole in increasing students learning motivation. Learning activities can be successful if there is a role for the teacher in the teaching process. This success depends a lot on the efforts of the teacher in arousing the motivation to learn of students. Therefore, it's important to create certain conditions so that students are always motivation and want to continue learning. The study is a quasiexperimental research. The research population was all the learning groups of grade XI MIPA students at SMAN 9 Pinrang of academic year 2020/2021 which consisted of three learning groups. The samples were 
selected by employing simple random sampling technique and obtained two learning groups, namely the experiment group and the control group. Data collection technique employed questionnaire of learning motivation and test of learning outcomes. Data were analyzed descriptively and inferentially with the help of IBM SPSS Statistics version 22 for Windows application. The results of the study reveal that (i) the students' learning motivation through the utilization of the module of Network in Plants based on scientific approach is in high category, (ii) the students' learning motivation through the utilization of Biology package books is in low category, and (iii) there are differences of students' learning motivation through the utilization of the module of Network in Plants based on scientific approach and Biology package books.

Keyword: Module of network in plants based on scientific approach, biology package books, and learning motivation. 


\section{PENDAHULUAN}

Pendidikan merupakan salah satu upaya untuk memberikan pengetahuan wawasan, keterampilan dan keahlian tertentu kepada individu-individu guna menggali dan mengembangkan bakat serta kepribadian mereka. Dengan kata lain, pendidikan umumnya berperan penting dalam meningkatkan kualitas sumber daya manusia (SDM) dan berdaya saing tinggi dalam upaya mewujudkan kesejahteraan umum dan mencerdaskan kehidupan bangsa. Realita kualitas pendidikan yang ada di Indonesia dikatakan menurun atau rendah dibandingkan dengan negaranegara lainnya. Salah satu aspek yang dapat mempengaruhi kualitas pendidikan yaitu bahan ajar.

Bahan ajar yang ada terkadang membuat peserta didik merasa tidak senang dan merasa bosan dalam mempelajarinya. Ketidaksenangan dan kebosanan peserta didik akan mengakibatkan turunnya motivasi belajar peserta didik dan berujung pada menurunnya kemampuan kognitif peserta didik. Motivasi dan kemampuan kognitif merupakan dua masalah yang selalu terangkai dalam sebuah sistem pembelajaran. Secara umum bila motivasi belajar peserta didik tinggi, maka kecenderungannya adalah kemampuan kognitif peserta didik juga tinggi ataupun sebaliknya.

Motivasi merupakan tanggung jawab seorang guru agar pengajaran yang diberikan berhasil dengan baik. Keberhasilan ini banyak bergantung pada usaha guru dalam membangkitkan motivasi belajar peserta didik. Motivasi menentukan tingkat keberhasilan atau kegagalan belajar pada peserta didik (Sutrisno, et al. 2012). Oleh karena itu, penting menciptakan kondisi tertentu agar peserta didik selalu termotivasi dan ingin terus belajar. Memandang situasi dan kondisi itu, maka seorang guru yang kreatif harus dapat meningkatkan motivasi belajar peserta didik dalam mempelajari dan mengusahakan suatu cara atau metode lain yang dapat membantu peserta didik agar lebih termotivasi dalam belajar. Sehingga nantinya, hasil belajar yang diperoleh peserta didik menjadi lebih baik.

Salah satu cara untuk meningkatkan motivasi belajar peserta didik adalah penggunaan bahan ajar berupa modul berbasis pendekatan saintifik. Modul berbasis pendekatan saintifik adalah modul yang disusun melalui proses pengamatan maupun percobaan dengan mendapatkan tambahan informasi dari berbagai sumber dengan proses mengamati (observing), menanya (questioning), mencoba (experimenting), menalar atau asosiasi (associating) dan mengkomunikasikan (commucicating) (Fadillah, 2014).

Modul berbasis pendekatan saintifik sangat penting digunakan dalam kegiatan pembelajaran terutama pada kurikulum 2013. Hal ini dikarenakan modul berbasis pendekatan saintifik memberikan keseimbangan, melatih serta memperkuat kompetensi peserta didik dalam hal sikap, pengetahuan dan kemampuan peserta didik secara utuh (Firman, et al. 2018). Modul berbasis pendekatan saintifik yang digunakan harus disesuaikan dengan minat, perhatian dan kebutuhan peserta didik (Wenno, 2010). Hal ini sejalan dengan pendapat Prastowo (2015) menyatakan bahwa modul berbasis pendekatan saintifik dapat mengaktifkan peserta didik untuk belajar secara mandiri tanpa atau bimbingan guru, meningkatkan motivasi belajar, prestasi belajar dan meningkatkan hasil belajar peserta didik.

Berdasarkan uraian permasalahan diatas maka perlu adanya pemanfaatan modul berbasis pendekatan saintifik dan buku paket biologi untuk menunjang proses pembelajaran, khususnya pembelajaran biologi di Sekolah Menengah Atas. Dalam hal ini, calon peneliti akan melaksanakan penelitian dengan judul "Efektivitas Pemanfaatan Modul Jaringan pada Tumbuhan Berbasis Pendekatan Saintifik dan Buku Paket Biologi Terhadap Motivasi Belajar Peserta Didik di SMA Negeri 9 Pinrang". 


\section{METODE}

Penelitian ini termasuk penelitian Quasi Experimental. Penentuan sampel penelitian dilakukan dengan teknik simple random sampling, kemudian didapatkan dua rombongan belajar yang dijadikan sebagai kelas eksperimen dan kelas kontrol. Hasil random tersebut terpilih kelas XI MIPA 1 dijadikan sebagai kelas eksperimen melalui pemanfaatan modul jaringan pada tumbuhan berbasis pendekatan saintifik dan kelas XI MIPA 2 dijadikan sebagai kelas kontrol melalui pemanfaatan buku paket biologi. Populasi penelitian ini adalah seluruh rombongan belajar peserta didik kelas XI MIPA di SMA Negeri 9 Pinrang tahun ajaran 2020/2021 yang terdiri dari tiga rombongan belajar. Instrumen yang digunakan dalam penelitian ini adalah angket motivasi belajar peserta didik yang terdiri dari 25 item pernyataan. Desain penelitian yang digunakan adalah Pretest-Posttest Control Group Design. Pretest-posttest control group design adalah desain dengan memberikan dua perlakuan yang berbeda terhadap dua kelompok yaitu: kelompok eksperimen dan kelompok kontrol. Kelompok eksperimen dan kelompok kontrol diberikan angket motivasi belajar peserta didik sebelum penggunaan modul jaringan pada tumbuhan berbasis pendekatan saintifik dan buku paket biologi. Kelompok eksperimen maupun kelompok kontrol mendapatkan pembelajaran yang sama yaitu: pembelajaran konvensional yang dilakukan di dalam kelas. Selanjutnya, untuk kelompok eksperimen mendapatkan pembelajaran tambahan melalui penggunaan modul jaringan pada tumbuhan berbasis pendekatan saintifik, sedangkan kelompok kontrol mendapatkan pembelajaran tambahan melalui penggunaan buku paket biologi. Akhir dari proses pembelajaran kelompok eksperimen dan kelompok kontrol diberikan angket motivasi belajar peserta didik. Teknik analisis data dilakukan secara deskriptif dan analisis secara inferensial dengan bantuan program aplikasi IBM SPSS Statistic versi 22 for Windows.

\section{HASIL DAN PEMBAHASAN}

1. Hasil

Hasil motivasi belajar kelas eksperimen dan kelas kontrol dapat dilihat pada Tabel 1.

Tabel 1. Hasil Analisis Deksriptif Motivasi Belajar Peserta Didik Kelas Eksperimen dan Kelas Kontrol

\begin{tabular}{clcccc}
\hline \multirow{2}{*}{ No } & \multirow{2}{*}{ Uraian } & \multicolumn{2}{c}{ Kelas Eksperimen } & \multicolumn{2}{c}{ Kelas Kontrol } \\
\cline { 3 - 5 } & & Pretest & Posttest & Pretest & Posttest \\
\hline 1. & Nilai Maksimum & 100 & 100 & 100 & 100 \\
2. & Nilai Minimum & 32 & 48 & 28 & 40 \\
3. & Rata-Rata & 79.32 & 80.42 & 75.87 & 80.16 \\
4. & Standar Deviasi & 10.91 & 14.46 & 13.49 & 14.32 \\
5. & Jumlah Siswa & 31 & 31 & 31 & 31 \\
\hline
\end{tabular}

Sumber: Data Peneliti

Berdasarkan Tabel 1 menunjukkan bahwa nilai rata-rata peserta didik sebelum pemanfaatan modul jaringan pada tumbuhan berbasis pendekatan saintifik pada kelas eksperimen adalah 79.32 dan meningkat menjadi 80.42 sesudah pemanfaatan modul jaringan pada tumbuhan berbasis pendekatan saintifik dengan jumlah peserta didik sebanyak 31 orang peserta didik, sedangkan nilai rata-rata peserta didik sebelum pemanfaatan buku paket biologi pada kelas kontrol adalah 75.87 dan meningkat menjadi 80.16 sesudah pemanfaatan buku paket biologi dengan jumlah peserta didik yang sama dengan kelas eksperimen sebanyak 31 orang peserta didik. 
Kegiatan pembelajaran sebelum pemanfaatan modul jaringan pada tumbuhan berbasis pendekatan saintifik menyatakan bahwa sebagian besar peserta didik merasa bosan dalam belajar biologi karena hanya mencatat saja, sehingga peserta didik lebih senang berbicara sendiri tanpa memperhatikan penjelasan guru dan peserta didik tidak dapat menemukan pemecahan dari permasalahan yang mereka hadapi, sedangkan sesudah pemanfaatan modul jaringan pada tumbuhan berbasis pendekatan saintifik menyatakan bahwa peserta didik senang belajar biologi karena dapat membantu dalam memahami pembelajaran khususnya dalam kegiatan praktikum, peserta didik juga mampu mengaitkan materi pembelajaran sebelumnya dengan materi yang akan dipelajari, peserta didik dapat menemukan pemecahan masalah dari permasalahan yang dihadapi dan peserta didik menjadi lebih aktif dan mandiri dalam proses pembelajaran melalui penggunaan modul jaringan pada tumbuhan berbasis pendekatan saintifik. Modul jaringan pada tumbuhan berbasis pendekatan saintifik yang digunakan peserta didik dalam proses pembelajaran biologi dilengkapi dengan cover, kata pengantar, daftar isi, kompetensi inti, kompetensi dasar, tujuan pembelajaran yang hendak dicapai, petunjuk penggunaan modul, peta konsep, kegiatan belajar yang berbasis saintifik melalui kegiatan mengamati, menanya, mencoba, menalar dan mengkomunikasikan, rangkuman, tes mandiri, tindak lanjut, evaluasi dan daftar pustaka.

Hal ini tentunya berbeda dengan peserta didik kelas kontrol sebelum dan sesudah penggunaan buku paket biologi menyatakan bahwa sebagian besar siswa merasa bosan dan tidak tertarik belajar biologi, karena peserta didik lebih banyak berbicara sendiri dengan temannya saat guru menyampaikan materi, akibatnya peserta didik menjadi kurang aktif dan tidak mandiri dalam proses pembelajaran. Buku paket biologi yang digunakan peserta didik dalam proses pembelajaran meliputi beberapa komponen yaitu judul, materi pembelajaran, standar kompetensi, kompetensi dasar, indikator, petunjuk belajar, tujuan yang dicapai, informasi pendukung, latihan, petunjuk kerja dan penilaian.

Data distribusi, pengkategorian, frekuensi dan persentase nilai motivasi belajar peserta didik kelas eksperimen melalui pemanfaatan modul berbasis pendekatan saintifik dan kelas kontrol melalui pemanfaatan buku paket biologi dapat dilihat pada Tabel 2.

Tabel 2. Distribusi Frekuensi, Kategori dan Persentase Nilai Motivasi Belajar Peserta Didik Kelas Eksperimen dan Kelas Kontrol

\begin{tabular}{|c|c|c|c|c|c|}
\hline \multicolumn{6}{|c|}{ Sebelum Perlakuan } \\
\hline \multirow{2}{*}{ Interval Nilai } & \multirow{2}{*}{ Kategori } & \multicolumn{2}{|c|}{ Kelas Eksperimen } & \multicolumn{2}{|c|}{ Kelas Kontrol } \\
\hline & & Frekuensi & Persentase (\%) & Frekuensi & Persentase (\%) \\
\hline$X \geq 100$ & Sangat tinggi & 4 & 12.8 & 4 & 12.8 \\
\hline $83 \leq X<100$ & Tinggi & 13 & 42 & 9 & 29.2 \\
\hline $67 \leq x<83$ & Sedang & 9 & 29.2 & 8 & 25.8 \\
\hline $50 \leq X<67$ & Rendah & 3 & 9.6 & 5 & 16.1 \\
\hline$x<50$ & Sangat rendah & 2 & 6.4 & 5 & 16.1 \\
\hline \multicolumn{6}{|c|}{ Sesudah Perlakuan } \\
\hline \multirow[b]{2}{*}{ Interval Nilai } & \multirow[b]{2}{*}{ Kategori } & \multicolumn{2}{|c|}{ Kelas Eksperimen } & \multicolumn{2}{|c|}{ Kelas Kontrol } \\
\hline & & Frekuensi & $\begin{array}{c}\text { Persentase } \\
(\%)\end{array}$ & Frekuensi & Persentase (\%) \\
\hline$X \geq 100$ & Sangat tinggi & 8 & 25.8 & 4 & 12.8 \\
\hline $83 \leq X<100$ & Tinggi & 10 & 32.4 & 11 & 35.5 \\
\hline $67 \leq x<83$ & Sedang & 5 & 16.1 & 12 & 38.9 \\
\hline $50 \leq x<67$ & Rendah & 5 & 16.1 & 2 & 6.4 \\
\hline$x<50$ & Sangat rendah & 3 & 9.6 & 2 & 6.4 \\
\hline
\end{tabular}

Sumber: Data Peneliti 
Tabel 2 menunjukkan bahwa motivasi belajar peserta didik sebelum mengikuti pembelajaran melalui pemanfaatan modul jaringan pada tumbuhan berbasis pendekatan saintifik terdapat 13 orang peserta didik dengan persentase sebesar $42 \%$ berada pada kategori tinggi, sedangkan motivasi belajar peserta didik sebelum mengikuti pembelajaran melalui pemanfaatan buku paket biologi terdapat 9 orang dengan persentase sebesar $29.2 \%$ berada pada kategori tinggi. Motivasi belajar peserta didik sesudah mengikuti pembelajaran melalui pemanfaatan modul jaringan pada tumbuhan berbasis pendekatan saintifik terdapat 10 orang dengan persentase sebesar $32.4 \%$ berada pada kategori tinggi, sedangkan motivasi belajar peserta didik sesudah mengikuti pembelajaran melalui pemanfaatan buku paket biologi terdapat 12 orang dengan persentase sebesar $38.9 \%$ berada pada kategori sedang.

Dengan demikian, dapat disimpulkan bahwa hasil motivasi belajar peserta didik sesudah penggunaan modul jaringan pada tumbuhan berbasis pendekatan saintifik kelas eksperimen sangat tinggi dibandingkan hasil motivasi belajar peserta didik sesudah penggunaan buku paket biologi kelas kontrol.

Data distribusi pengkategorian, frekuensi dan persentase peningkatan nilai motivasi belajar peserta didik kelas eksperimen melalui penggunaan modul jaringan pada tumbuhan berbasis pendekatan saintifik dan kelas kontrol melalui penggunaan buku paket biologi dapat dilihat pada Tabel 3.

Tabel 3. Distribusi Frekuensi, Kategori dan Persentase Peningkatan Nilai Motivasi Belajar Peserta Didik Kelas Eksperimen dan Kelas Kontrol

\begin{tabular}{cccccc}
\hline \multirow{2}{*}{ Interval Nilai } & \multirow{2}{*}{ Kategori } & \multicolumn{2}{c}{ Kelas Eksperimen } & \multicolumn{2}{c}{ Kelas Kontrol } \\
\cline { 3 - 6 } & & Frekuensi & Persentase (\%) & Frekuensi & Persentase (\%) \\
\hline $0,70 \leq \mathrm{N} \leq 1,00$ & Tinggi & 13 & 41.6 & 4 & 13.1 \\
$0,30 \leq \mathrm{N}<0,70$ & Sedang & 9 & 29.2 & 12 & 38.5 \\
$0,00 \leq \mathrm{N}<0,30$ & Rendah & 9 & 29.2 & 15 & 48.4 \\
\hline
\end{tabular}

Sumber: Data Peneliti

Tabel 3 menunjukkan bahwa motivasi belajar peserta didik kelas eksperimen melalui pemanfaatan modul berbasis pendekatan saintifik terdapat 13 orang dengan persentase sebesar $41.6 \%$ berada pada kategori tinggi, 9 orang dengan persentase sebesar $29.2 \%$ berada pada kategori sedang dan 12 orang dengan persentase sebesar $29.2 \%$ berada pada kategori rendah, sedangkan motivasi belajar peserta didik kelas kontrol melalui pemanfaatan buku paket biologi terdapat 4 orang dengan persentase sebesar $13.1 \%$ berada pada kategori tinggi, 12 orang dengan persentase sebesar $38.5 \%$ berada pada kategori sedang dan 15 orang dengan persentase sebesar $48.4 \%$ berada pada kategori rendah. Dengan demikian, dapat disimpulkan bahwa hasil motivasi belajar peserta didik kelas eksperimen melalui pemanfaatan modul jaringan pada tumbuhan berbasis pendekatan saintifik meningkat dibandingkan kelas kontrol melalui pemanfaatan buku paket biologi.

Analisis inferensial motivasi belajar peserta didik kelas eksperimen berasal dari populasi yang berdistribusi normal, sedangkan motivasi belajar peserta didik kelas kontrol berasal dari populasi yang berdistribusi normal dengan kesimpulan yaitu sig $=>0.05$. Hasil pengujian homogenitas sebelum dan sesudah pemanfaatan modul jaringan pada tumbuhan berbasis pendekatan saintifik pada kelas eksperimen dan pemanfaatan buku paket biologi pada kelas kontrol adalah 0.112, sehingga nilai sig $=0.112>0.05$.

Berdasarkan hasil pengujian normalitas dan homogenitas varians, maka dilakukan uji hipotesis dengan menggunakan Independent Samples T-Test. Hasil pengujian hipotesis diperoleh nilai sig sebesar 0.034. Dengan demikian, dapat disimpulkan bahwa nilai sig $=0.034<0.05$ dalam hal ini $\mathrm{H}_{\mathrm{o}}=$ ditolak dan $\mathrm{H}_{1}=$ diterima, yang berarti ada perbedaan signifikan antara motivasi belajar 
peserta didik melalui pemanfaatan modul jaringan pada tumbuhan jaringan pada tumbuhan berbasis pendekatan saintifik dan buku paket biologi kelas XI MIPA SMA Negeri 9 Pinrang.

\section{Pembahasan}

Berdasarkan penelitian yang dilakukan, didapatkan hasil bahwa ada perbedaan motivasi belajar peserta didik kelas eksperimen melalui pemanfaatan modul jaringan pada tumbuhan berbasis pendekatan saintifik dan kelas kontrol melalui pemanfataan buku paket biologi. Hal ini dapat dilihat dari hasil analisis angket motivasi pada item ke-14 yang menyatakan bahwa "saya dapat menemukan pemecahan dari permasalahan yang saya hadapi" ini menunjukkan bahwa siswa harus mampu menemukan pemecahan dari permasalahan yang dihadapi melalui kegiatan mengamati, menanya, mencoba, menalar dan mengkomunikasikan dalam setiap kegiatan pembelajaran melalui penggunaan modul jaringan pada tumbuhan berbasis pendekatan saintifik. Pemanfaatan modul jaringan pada tumbuhan berbasis pendekatan saintifik dalam proses pembelajaran akan lebih bermakna, sehingga timbul motivasi belajar yang positif.

Hasil penelitian tersebut sejalan dengan hasil penelitian Nasihin, et al. (2016) menyatakan bahwa modul yang disusun berdasarkan pendekatan saintifik yang dikenal dengan nama $5 \mathrm{M}$ yaitu, mengamati, menanya, mencoba, menalar dan mongkomunikasikan dapat meningkatkan hasil belajar siswa dan persepsi siswa terhadap isi modul serta pembelajaran dengan bantuan modul dapat meningkatkan motivasi yang sangat positif. Motivasi belajar juga memiliki peranan yang besar terhadap penguasaan materi siswa, karena apabila materi yang dipelajari tidak sesuai dengan motivasi siswa, maka siswa tidak akan belajar dengan optimal. Jika motivasi belajar siswa tinggi maka, seharusnya penguasaan materi yang dimiliki juga akan tinggi dan sebaliknya jika motivasi belajarnya rendah maka, penguasaan materi yang dimiliki juga akan rendah (Sardiman, 2010). Pembelajaran dengan menggunakan modul berbasis pendekatan saintifik menjadikan pembelajaran yang lebih kritis dan menuntut peserta didik lebih kritis dalam berpikir (Pintrich, $P$. R. 2003). Modul berbasis pendekatan saintifik dapat digunakan sebagai bahan ajar mandiri tanpa bimbingan seseorang guru (Roslina, 2017).

Modul jaringan pada tumbuhan berbasis pendekatan saintifik yang digunakan peserta didik kelas eksperimen dalam proses pembelajaran biologi dilengkapi dengan cover, kata pengantar, daftar isi, kompetensi inti, kompetensi dasar, tujuan pembelajaran yang hendak dicapai, petunjuk penggunaan modul, peta konsep, kegiatan belajar yang berbasis saintifik melalui kegiatan mengamati, menanya, mencoba, menalar dan mengkomunikasikan, rangkuman, tes mandiri, tindak lanjut, evaluasi dan daftar pustaka sedangkan buku paket biologi yang digunakan peserta didik kelas kontrol dalam proses pembelajaran dilengkapi dengan judul, materi pembelajaran, standar kompetensi, kompetensi dasar, indikator, petunjuk belajar, tujuan yang dicapai, informasi pendukung, latihan, petunjuk kerja dan penilaian. Dengan demikian, adanya modul jaringan pada tumbuhan berbasis pendekatan saintifik dalam proses pembelajaran dapat meningkatkan motivasi peserta didik untuk belajar lebih giat lagi dalam menghadapi materi yang diberikan oleh guru apabila ditinjau dari komponen yang dimilikinya.

Hasil penelitian tersebut sejalan dengan hasil penelitian Nasihin, et al. (2016) menyatakan bahwa modul yang disusun berdasarkan pendekatan saintifik yang dikenal dengan nama $5 \mathrm{M}$ yaitu, mengamati, menanya, mencoba, menalar dan mongkomunikasikan dapat meningkatkan hasil belajar peserta didik dan persepsi peserta didik terhadap isi modul serta pembelajaran dengan bantuan modul dapat meningkatkan motivasi yang sangat positif. Motivasi belajar sangat penting dalam menentukan hasil belajar peserta didik (Aritonang, 2008). Semakin tinggi motivasi belajar peserta didik, maka semakin tinggi pula peserta didik memperoleh prestasi akademiknya (Uno, 2017). Penggunan suatu media harus disesuaikan secara tepat dengan karakteristik materi pelajaran dan kebutuhan peserta didik (Bedduside, N \& Hadis, 2019). 
Berdasarkan penelitian tersebut, dapat disimpulkan bahwa motivasi belajar dapat menentukan hasil belajar peserta didik. Suatu proses dikatakan berhasil apabila hasil belajar peserta didik meningkat atau mengalami perubahan positif setelah peserta didik melakukan aktivitas belajar yang mendukung pelaksanaan kegiatan proses pembelajaran.

\section{KESIMPULAN}

Berdasarkan hasil penelitian yang diperoleh, dapat disimpulkan bahwa ada perbedaan motivasi belajar peserta didik melalui pemanfaatan modul jaringan pada tumbuhan berbasis pendekatan saintifik dan buku paket biologi di SMA Negeri 9 Pinrang.

\section{DAFTAR PUSTAKA}

Aritonang, K. T. 2008. Minat \& Motivasi dalam Meningkatkan Hasil Belajar Siswa. Jurnal Pendidikan Penabur, (online), No. 3, (http:// bpkpenabur.or.id/ Diakses 24 Agustus 2019).

Bedduside, N \& Hadis, A. 2019. Strategi Belajar Mengajar. Makassar. Universitas Negeri Makassar.

Daud, 2010. Pengaruh pembelajaran dengan metode pemberian tugas dan resitasi terhadap hasil belajar biologi siswa kelas XI SMA Negeri 3 Makassar. Bionature, (Online), Vol. 11 No. 2, (http://ojs.unm.ac.id, Diakses 06 November 2019).

Fadillah, M. 2014. Implementasi Kurikulum 2013. Yogyakarta: Ar-Ruzz Media.

Firman., Baedhowi., \& Murtini, W. 2018. The Effectiveness of The Scientific Approach to Improve Student Learning Outcomes. International Journal of Active Learning, (Online), Vol. 3, No. 2, (http://journal.unnes.ac.id, Diakses 26 Agustus 2019).

Keller, J. 1984. Development of Two Measures of Leaner Motivation, Florida State University, (Online), (http://www.scribd.com.Hakhwat/ARCSDraft-060222, Diakses 03 Oktober 2019).

Munadi, Y. 2010. Media Pembelajaran Sebuah Pendekatan Baru. Jakarta: Gaung Persada Press.

Nasihin, M., Juhmhari, M., \& Sulaeman, S.M. 2016. Pendekatan Scientific Dapat Meningkatkan Aktivitas dan hasil Belajar Siswa pada Mata Pelajaran IPA Di Kelas V SD IMPRES Kota Palu. ejurnal Mitra Sains (Online), Vol. 4 No. 1 (http://www.jurnal.untad.ac.id, Diakses 02 Februari 2020).

Pintrich, P. R. 2003. A Motivational Science Perspective On The Role of Student Motivation in Learning and Teaching Context. Journal of Education Psychology, (Online), Vol. 95, No. 4, (http://psycnet.apa.org, Diakses 21 Maret 2019).

Prastowo, A. 2015. Panduan Kreatif Membuat Bahan Ajar Inovatif. Yogyakarta: Diva Press.

Roslina. 2017. Pengembangan Modul BerbaDisis Pendekatan Saintifik sebagai Bahan Ajar Biologi pada Materi Struktur dan Fungsi Jaringan Tumbuhan-Hewan untuk Siswa Kelas XI SMA/MA. Skripsi. Tidak diterbitkan. Tarakan: Universitas Borneo Tarakan. 
Sardiman. 2010. Interaksi dan Motivasi Belajar Mengajar. Jakarta: PT. Raja Grafindo.

Shahzadi, I., Javed, A., Pirzada, S. S., Nasreen, S., \& Khanam, F. 2014. Impact of Employee Motivation on Employee Performance. European Journal of Business and Management, (Online), Vol. 6, No. 23, (http://pdfs.semantischolar.org, Diakses 26 Agustus 2019).

Sutrisno, W., Dwiastuti, S. \& Karyanto, P. 2012. Pengaruh Model Learning Cycle 7E Terhadap Motivasi Belajar Siswa dalam Pembelajaran Biologi. Seminar Nasional IX Pendidikan Biologi FKIP UNS, (Online), Vol. 9, No. 1, (http://www.jurnal.fkip.uns.ac.id, Diakses 07 Juni 2019).

Uno, H. B. 2017. Teori Motivasi dan Pengukurannya Analisis di Bidang Pendidikan. Jakarta: Bumi Aksara.

Wenno, I. H. 2010. Pengembangan Model Modul IPA Berbasis Problem Solving Method Berdasarkan Karakteristik Siswa dalam Pembelajaran di SMP/MTS.

\section{Roslina}

Mahasiswa Jurusan Biologi, Pascasarjana Universitas Negeri Makassar. Jl. Bonto Langkasa, Kampus UNM Gunungsari Baru, Makassar, dapat dihubungi melaui email: roslina95@yahoo.com.

\section{Nurhayati B}

Dosen Jurusan Biologi, Fakultas Matematika dan Ilmu Pengetahuan Alam Universitas Negeri Makassar. Jl. Daeng Tata Raya, Makassar, dapat dihubungi melaui email: nurhayati.b@unm.ac.id.

\section{Rachmawaty}

Dosen Jurusan Biologi, Fakultas Matematika dan Ilmu Pengetahuan Alam Universitas Negeri Makassar. Jl. Daeng Tata Raya, Makassar, dapat dihubungi melaui email: rachmawaty@unm.ac.id. 